Wilfrid Laurier University

Scholars Commons @ Laurier

Geography and Environmental Studies Faculty

Publications

Geography and Environmental Studies

3-2007

\title{
From Isotopes to TK Interviews: Towards Interdisciplinary Research in Fort Resolution and the Slave River Delta, Northwest Territories
}

\author{
Brent B. Wolfe \\ Wilfrid Laurier University, bwolfe@wlu.ca \\ Derek Armitage \\ Wilfrid Laurier University, darmitage@wlu.ca \\ Bronwyn E. Brock \\ University of Waterloo \\ Michael A. Sokal \\ University of Waterloo \\ Kenneth P. Clogg-Wright \\ University of Waterloo
}

See next page for additional authors

Follow this and additional works at: https://scholars.wlu.ca/geog_faculty

\section{Recommended Citation}

Wolfe, Brent B.; Armitage, Derek; Brock, Bronwyn E.; Sokal, Michael A.; Clogg-Wright, Kenneth P.; Mongeon, Cherie L.; Adam, Margaret E.; Hall, Roland I.; and Edwards, Thomas W.D., "From Isotopes to TK Interviews: Towards Interdisciplinary Research in Fort Resolution and the Slave River Delta, Northwest Territories" (2007). Geography and Environmental Studies Faculty Publications. 3.

https://scholars.wlu.ca/geog_faculty/3

This Article is brought to you for free and open access by the Geography and Environmental Studies at Scholars Commons @ Laurier. It has been accepted for inclusion in Geography and Environmental Studies Faculty Publications by an authorized administrator of Scholars Commons @ Laurier. For more information, please contact scholarscommons@wlu.ca. 


\section{Authors}

Brent B. Wolfe, Derek Armitage, Bronwyn E. Brock, Michael A. Sokal, Kenneth P. Clogg-Wright, Cherie L. Mongeon, Margaret E. Adam, Roland I. Hall, and Thomas W.D. Edwards 


\title{
From Isotopes to TK Interviews: Towards Interdisciplinary Research in Fort Resolution and the Slave River Delta, Northwest Territories
}

\author{
BRENT B. WOLFE, $, 1,2,3$ DEREK ARMITAGE, ${ }^{1}$ SONIA WESCHE, ${ }^{1}$ BRONWYN E. BROCK, ${ }^{2}$ MICHAEL A. SOKAL, ${ }^{4}$ \\ KENNETH P. CLOGG-WRIGHT, ${ }^{2}$ CHERIE L. MONGEON, ${ }^{1}$ MARGARET E. ADAM,${ }^{4}$ ROLAND I. HALL ${ }^{4}$ \\ and THOMAS W.D. EDWARDS ${ }^{2}$
}

(Received 6 January 2006; accepted in revised form 16 October 2006)

\begin{abstract}
Evolving research in Fort Resolution and the Slave River Delta, Northwest Territories, aims to improve understanding of how the natural ecosystem functions and responds to various environmental stressors, as well as to enhance the stewardship of natural resources and the capacity of local residents to respond to change. We seek to integrate approaches that span the natural and social sciences and traditional knowledge understandings of change, employing a research design developed in response to the concerns of a northern community. In doing so, we have strived for a research process that is collaborative, interdisciplinary, policy-oriented, and reflective of northern priorities. These elements characterize the new northern research paradigm increasingly promoted by various federal funding agencies, northern partners, and communities. They represent a holistic perspective in the pursuit of solutions to address complex environmental and socioeconomic concerns about impacts of climate change and resource development on northern societies. However, efforts to fulfill the objectives of this research paradigm are associated with a host of on-the-ground challenges. These challenges include (but are not restricted to) developing effective community partnerships and collaboration and documenting change through interdisciplinary approaches. Here we provide an overview of the components that comprise our interdisciplinary research program and offer an accounting of our formative experiences in confronting these challenges.
\end{abstract}

Key words: hydroecology, climate change, environmental change, paleolimnology, traditional knowledge, resource management, adaptive capacity, northern Canada, partnerships, sustainability

RÉSUMÉ. Des travaux de recherche en cours à Fort Resolution et dans le delta de la rivière des Esclaves, aux Territoires du NordOuest, visent à mieux comprendre le fonctionnement de l'écosystème naturel, à réagir aux divers facteurs d'agression environnementaux ainsi qu'à rehausser la gérance des ressources naturelles et la capacité des habitants de la région à réagir au changement. Nous cherchons à intégrer des méthodes qui englobent les sciences naturelles et sociales et favorisent la compréhension du changement du point de vue des connaissances traditionnelles. Nous cherchons également à employer une méthodologie respectueuse des inquiétudes de la collectivité du Nord. Ce faisant, nous avons abouti à un processus de recherche caractérisé par la collaboration, l'interdisciplinarité et les politiques, processus qui tient également compte des priorités dans le Nord. Ces éléments définissent le nouveau paradigme de recherche dans le Nord qui est de plus en plus préconisé par divers organismes de subvention fédéraux, partenaires du Nord et collectivités. Ils représentent une perspective holistique en guise de solutions à des enjeux environnementaux et socioéconomiques complexes portant sur les incidences du changement climatique et de l'exploitation des ressources sur les sociétés du Nord. Toutefois, les efforts visant à concrétiser les objectifs de ce paradigme de recherche font face à une multitude de défis. Ces défis comprennent (mais sans s'y restreindre) la formation de partenariats efficaces avec les collectivités, des efforts de collaboration et la prise de notes sur les changements qui s'opèrent grâce à des méthodes interdisciplinaires. Ici, nous fournissons un aperçu des éléments de notre programme de recherche interdisciplinaire et donnons un aperçu de l'expérience formative qui a découlé de ces défis.

Mots clés : hydroécologie, changement climatique, changement environnemental, paléolimnologie, connaissances traditionnelles, gestion des ressources, capacité d'adaptation, nord du Canada, partenariats, durabilité

Traduit pour la revue Arctic par Nicole Giguère.

\footnotetext{
${ }^{1}$ Department of Geography and Environmental Studies, Wilfrid Laurier University, 75 University Avenue West, Waterloo, Ontario N2L 3C5, Canada

${ }^{2}$ Department of Earth Sciences, University of Waterloo, Waterloo, Ontario N2L 3G1, Canada

${ }^{3}$ Corresponding author: bwolfe@wlu.ca

${ }^{4}$ Department of Biology, University of Waterloo, Waterloo, Ontario N2L 3G1, Canada

(C) The Arctic Institute of North America
} 


\section{INTRODUCTION}

In northern regions experiencing environmental change, successful research strategies and policy directions need to draw upon and integrate the knowledge and experience of Northerners, along with contributions from Western natural and social science. Northern residents are increasingly articulating the message that responses to the complexities of environmental change are most likely to emerge through interdisciplinary understanding and meaningful collaboration (Armitage and Clark, 2005; Berkes et al., 2005). Interdisciplinary and collaborative research strategies are developing because researchers and practitioners (e.g., decision makers, land users) recognize the valuable knowledge that community-based participants bring, as partners in research design and implementation, to local, regional, and global studies of environmental change (McDonald et al., 1997; Krupnik and Jolly, 2002).

The unique and complex nature of northern research challenges and opportunities were the focus of the Dialogue on Northern Research (DNR) held in Whitehorse, Yukon, on 25-27 March 2004 and the recent follow-up publication, From Opportunity to Action: A Progress Report on Canada's Renewal of Northern Research (Graham and Fortier, 2005). A principal objective of the DNR was to identify "actions to improve collaboration between researchers from the natural, social and health sciences, as well as users and funders of northern research" (Graham and Fortier, 2005:9). Two of the many recommendations were to "develop resident capacity and northern involvement in all stages of research in local, national and international issues" (Graham and Fortier, 2005:24) and to "ensure sensitivity to northern needs and to encourage the integration of Traditional Knowledge with other scientific findings" (Graham and Fortier, 2005:26). Responding to these and other recommendations, however, poses significant challenges: these include operating within funding constraints, coordinating southern-based university research efforts with the needs and priorities of northern communities, integrating disparate research approaches, and finding effective and useful ways of communicating research results to local stakeholders (Korsmo and Graham, 2002; Wein, 2002; Armitage and Clark, 2005).

Our purpose here is to detail the development of an interdisciplinary research program that addresses gaps in knowledge about environmental change in the Slave River Delta and nearby community of Fort Resolution, Northwest Territories (Fig. 1). We highlight efforts to incorporate key recommendations of the DNR (Graham and Fortier, 2005) and to document the evolving process and emerging outcomes of a new research paradigm in northern Canadaresearch that aims to be collaborative, interdisciplinary, policy-oriented, and reflective of northern priorities. We recognize that these terms represent a spectrum of possibilities and approaches, although we use more defined interpretations of the latter two terms in particular. Research that reflects northern priorities entails a collaborative relationship among communities, other northern partners, and researchers, who work together to arrive at research questions and objectives. Research that is policy-oriented similarly emerges from these collaborations that connect researchers and research outcomes with northern decision makers, especially at the local and regional levels (Fig. 1).

While idealized concepts inherent in this paradigm are attractive, uncritical enthusiasm should be tempered by an accounting of the challenges such research approaches entail. Thus, our objectives are 1) to describe a broad range of environmental investigations that blend ongoing input, direction, and support of a northern community with the efforts of a team of southern university-based natural and social scientists; 2) to document various strategies we have used to overcome challenges associated with developing northern partnerships; and 3) to identify opportunities and difficulties linked to the integration of Western science and traditional knowledge approaches. Ultimately, integration of our research findings is aimed at enhancing environmental stewardship of the Slave River Delta and the adaptive capacity of the community of Fort Resolution. Although we do not offer a textbook procedure for this emerging research paradigm, lessons learned may be useful for similar interdisciplinary research initiatives in other northern communities that are experiencing and adapting to the varied effects of environmental change.

\section{FORT RESOLUTION AND THE SLAVE RIVER DELTA, NORTHWEST TERRITORIES: COMPONENTS OF AN INTEGRATED RESEARCH INITIATIVE}

The Slave River Delta (SRD), Northwest Territories, Canada, located at the mouth of the Slave River where it enters Great Slave Lake from the south (Fig. 2), is a highly productive ecosystem that supports a wide variety of wildlife and numerous riparian plant communities (Milburn et al., 1999). Biological productivity and diversity in the SRD are closely linked to the hydrology of the Slave River: water and nutrient-rich sediment supplied during flood events are thought to sustain the extensive shoreline habitat and overall vitality of this northern ecosystem (English et al., 1997; Prowse et al., 2002). The natural resources of the delta have also been historically important to the Dené and Métis of nearby Fort Resolution (population 550; Fig. 2) for hunting, trapping, and fishing. In recent decades, increased access to other goods and services, as well as local economic diversification, has provided some alternative employment opportunities and sources of subsistence for the people of Fort Resolution. Strong sociocultural connections to the SRD remain, however, and a proportion of the population continues to participate in traditional lifestyle occupations dependent upon the delta ecosystem.

In recent years, increased recognition of the potential impacts of various stressors on SRD hydroecology, 


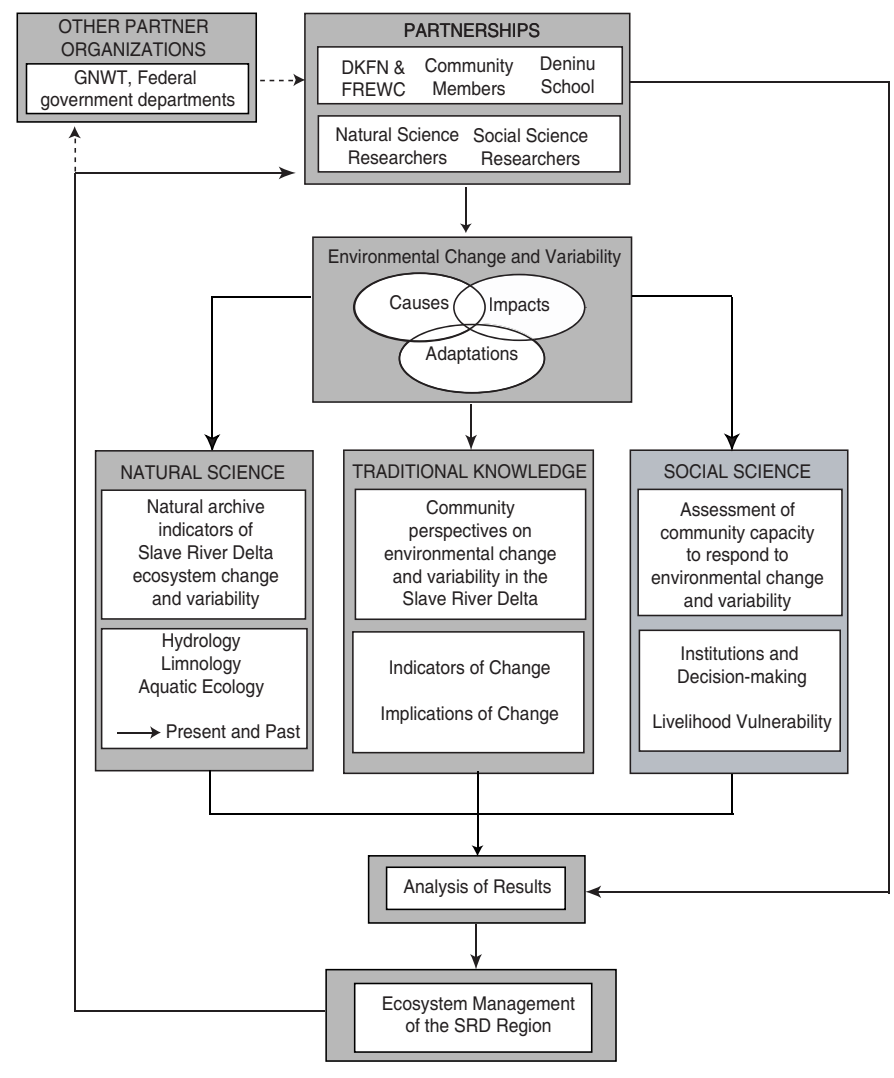

FIG. 1. Conceptual diagram of the interdisciplinary environmental change research initiative in Fort Resolution and the Slave River Delta, Northwest Territories. The research process is participatory and iterative, and it promotes ongoing communication between researchers and community partners.

including river regulation and climate variability, has raised concerns regarding the current state of the ecosystem that have implications for resource management of the delta and the community of Fort Resolution. Large multiagency research programs, including the Northern River Basins Study (NRBS; Gummer et al., 2000), have attempted to ascertain the downstream effects of the W.A.C. Bennett Dam, which was constructed on the Peace River in 1968 for hydroelectric production (Fig. 2). This industrial development, long a focus of controversy over perceived impacts on the Peace-Athabasca Delta (PAD) upstream of the SRD (Fig. 2), has been the subject of several prior environmental studies over the past 35 years (e.g., PADPG, 1973; PADIC, 1987; PADTS, 1996). As part of the NRBS, English et al. (1997) identified changes in SRD plant assemblages and landform constructional processes from a series of historical aerial photographs dating back to 1946. The photographs indicated drier and less productive conditions after regulation of the Peace River, consistent with local observations (Bill et al., 1996). However, limited scientific knowledge of natural geomorphic and vegetation changes in the SRD and its response to climate variability and change have brought into question speculative links to the effects of flow regulation (Timoney, 2002). Further complications arise because hydrometric and climate records are insufficient in length to clearly explore relationships between apparent drying of the delta over the past few decades and a host of potential causes, which include lower river discharge, reduced flood frequency, natural deltaic evolution, and climate variability. Thus, the relative roles of various driving forces on contemporary and evolving hydroecological conditions of the SRD remain largely indeterminate (Prowse et al., 2002). In response to this challenging and uncertain context, we have developed an integrated research initiative that draws upon three broad approaches and themes (Fig. 1), each of which is briefly summarized below.

\section{Environmental Variability and Change: Natural Archives of Present and Past Hydroecology}

Extensive research has recently been conducted to gain better understanding of present and past hydroecological conditions in the Peace-Athabasca Delta (PAD; see Wolfe et al., 2002), $300 \mathrm{~km}$ to the south of the SRD. Studies have comprised 1) widespread sampling of surface waters from lakes, wetlands, and rivers for analysis of chemistry, nutrients, biota, and water isotopes to characterize the range of modern hydrological and ecological conditions and 2) stratigraphic analyses of lake sediment, using a broad suite of chemical, biological, and physical parameters to reconstruct site-specific hydroecological histories. The primary motivation for these studies was to address long-held community and government concerns related to perceived downstream hydroecological effects of the W.A.C. Bennett Dam on the PAD (a focus which has since been extended to the SRD).

In the absence of long-term hydrometric and climate data, paleoenvironmental records from lake sediment stratigraphies were used to answer the following questions: 1) what is the range of natural variability of hydroecological conditions in the delta, and how is that related to climatic variability, flood frequency and geomorphic change? 2) does natural variability include multi-decadal periods without major flooding and low lake levels? and 3 ) has flow regulation had any perceptible (i.e., directional) influence on hydroecological conditions in the delta?

Building on the success of these studies in the PAD (Hall et al., 2004; Wolfe et al., 2005, 2006a, b, 2007), hydroecological investigations were initiated in the SRD in 2002 and are ongoing (Fig. 1). These investigations were designed to assess similar concerns of community members and other northern partners regarding potential hydroecological impacts of river regulation, as well as hydroclimatic change and variability. Studies have included intensive field-based modern process investigations on hydrology, limnology, and aquatic ecology from 2003 to 2005, which were years of varying hydroclimatic conditions in the SRD. For instance, spring melt conditions varied from moderate flooding in 2003 (further described below), to minor flooding in 2004, to major widespread flooding in 2005. As a result, exceptional data 


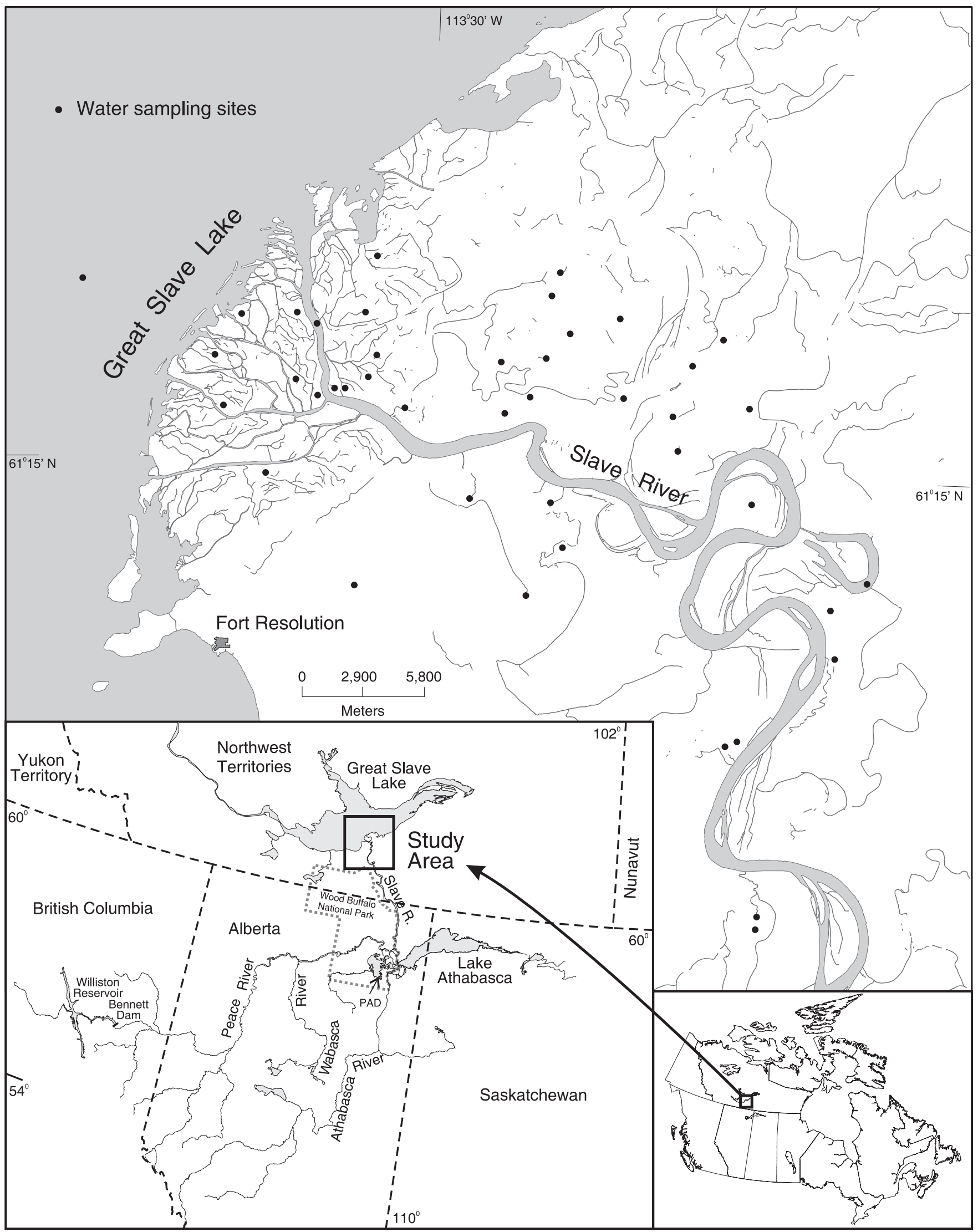

FIG. 2. Location of the Slave River Delta, lake and river sampling sites, and the nearby community of Fort Resolution, Northwest Territories. The inset at lower left shows the Peace-Athabasca Delta (PAD) to the south of the study area and the location of the W.A.C. Bennett Dam in British Columbia, near the headwaters of the Peace River. 
sets have been acquired to generate insight into the role of river flooding on shallow lake and wetland water balances, seasonal variations in limnology and their relationship with hydrological processes, and the responses of aquatic plant communities to hydrological and limnological variations. Use of water isotope tracers has led these investigations, and results have identified sub-regional landscapes in the SRD sensitive to climate and river discharge variability on the basis of hydrologic evolution of lake water balances over the 2003 thaw season (Brock et al., in press). These studies are also playing a critical role in constraining ongoing, multi-proxy reconstructions of past hydroecological conditions based on lake sediment cores obtained from several basins. For example, remarkably similar trends in hydrological variability have been reconstructed for the past 250 years in upland basins of the SRD and PAD, reflecting the strong regional control of climate variability on these two northern freshwater ecosystems (Mongeon et al., 2006).

\section{Environmental Variability and Change: Perspectives from the Residents of Fort Resolution}

The government of the Northwest Territories has a formal policy supporting the use of traditional knowledge (TK) in planning, management, and assessment (GNWT, 1993). Subsequently defined here, TK is the cumulative and evolutionary body of knowledge, practice, and belief regarding the relationships of living beings (humans included) with each other and with their environment that has been handed down through generations by cultural transmission (Berkes, 1999). A number of principles guide the GNWT (1993) policy, including recognition of the value of oral tradition as a reliable source of information and the importance of respect for communities, TK, and holders of TK. Correspondingly, strategies to include TK in studies of environmental assessment and change are becoming increasingly common (see Stevenson, 1996; Berkes, 1999; Usher, 2000; Sherry and Meyers, 2002). Similarly, efforts have increased to document TK and highlight the benefits associated with the use of TK when designing research programs and management strategies that emphasize sociocultural and ecological sustainability (Agrawal, 1995; McDonald et al., 1997; Sillitoe, 2002). These experiences have led to a better understanding of the ethical and methodological issues facing those who develop and implement such initiatives, and the ethnographic challenges associated with TK studies, including rights to access and control over the use of TK (Berkes, 1999; Hanson and VanFleet, 2003).

While valuable, however, much of this work has been "stand-alone" in nature. The application or integration of TK into research, planning, and policy often occurs along an alternative trajectory, and too often it is dissociated from formal science, rather than an integral component of the research process. Nonetheless, such efforts have led to important contributions and insights, including the importance of the human-environment relationship to individual and collective sociocultural identity (Bill et al., 1996). We have sought to build on these experiences and efforts. For example, from the point at which key members of the community voiced their interest as relayed below, our intent has been to collaboratively develop and implement the TK study in concert with the ongoing hydroecological studies (Fig. 1). Thus, drawing upon TK as well as natural and social science creates a favourable opportunity for comparative and concurrent analyses of change and for subsequent development of innovative, ecosystem-based management strategies and policy. The objectives of the TK component are 1) to develop a TK indicators and trends framework of environmental change by collecting and collaboratively analyzing observations concerning hydrological history and climatic change in the SRD; 2 ) to build an integrative methodological framework for climate and environmental change analysis using TK and Western science (natural and social) approaches suitable for application in similar contexts; and 3) to identify, through unique interdisciplinary analyses of flood history and climatic change (i.e., linking formal Western science and TK understandings of change), policy implications for ecosystem-based planning, management, and assessment in the SRD.

The development of the TK component has been collaborative and incremental. After the Fort Resolution Environmental Working Committee (FREWC) requested a TK study, a community meeting was held in 2004 to introduce the project idea and obtain feedback and suggestions for the overall approach and design. This initial planning meeting was attended by a number of elders, land users, FREWC members, and other individuals from the community. Community support for the project emerged from this meeting, but also concerns about how TK would be used and whether holders of TK and participants in the study would be compensated. It was recommended to create a steering committee specifically for the TK component of the project, which would develop a protocol to address key concerns about knowledge use and community benefits. During extended visits since that initial meeting, the researchers have conducted a variety of activities designed to meet the objectives of the TK component, including meetings with community leaders, projects with students of Fort Resolution Deninu School, and interviews and guided field trips with elders and land users.

\section{Building Adaptive Capacity to Respond to Environmental Variability and Change}

Northern latitudes are expected to experience the most significant changes as a result of global climate modification (ACIA, 2004), and the implications for water resources and hydrological regimes are particularly significant. Indeed, in the SRD region, water is a central issue for residents of Fort Resolution and surrounding 
areas because of its crucial role in sustaining ecosystem integrity. Examining the implications of this environmental change for the residents of Fort Resolution and their ability to adapt is a key component of the overall research initiative.

To address the issue of adaptability, this project is linking the results of the hydroecological and TK components to support an examination, based in social science, of ways in which a community can build its capacity to adapt to variability and change (see Fig. 1). Importantly, this approach extends the application of our interdisciplinary research into the domain of policy. Specifically, there are regional interests in further examinations of adaptive capacity. A key conclusion of participants and scientists at a climate change workshop sponsored by the Canadian Mackenzie Global Energy and Water Cycle Experiment Study (MAGS/GEWEX) in Fort Resolution on 11-12 July 2005 , for example, centred on the need to take science and TK findings into the realm of defining adaptation issues and requirements. Moreover, addressing adaptation issues by building on science and TK is a major program thrust for the Dené Nation as a whole, as it ties in with the work of the Arctic Athabaskan Council and its focus on climate change impacts and adaptation. High priorities for residents of Fort Resolution and the surrounding region are to assess how vulnerable they are to change or variability in the environment and to build their own adaptive capacity.

Policy-oriented questions that guide the adaptive capacity theme include the following: 1) How vulnerable is the community of Fort Resolution to environmental change and associated impacts? 2) What opportunities exist to build adaptive capacity in the community, e.g., through targeted training, institutional development, allocation of financial resources, or developing links among partner groups? and 3) How should vulnerability issues and capacity development be incorporated into community-based strategies and ecosystem management? To respond to these questions, a collaborative partnership between the research team and the community is essential. Building on the partnerships already established, the Deninu Ku'e First Nation (DKFN) in Fort Resolution supports the need for adaptation research, and the president of the local Métis council, at the July 2005 workshop mentioned above, urged further work on adapting to change. This effort to explore the adaptive capacity of Fort Resolution residents is still evolving. However, in concert with partners, this social science component is building on the results of the other research themes through activities such as qualitative, scenario-based vulnerability assessments with numerous focus groups, using hydroecological and TK data to explore different trajectories of change; semi-structured interviews with leaders and other key informants; and a household survey to assess adaptive capacity and implications of change for livelihoods.

\section{A NEW NORTHERN RESEARCH PARADIGM: OPPORTUNITIES, CHALLENGES, AND DIRECTIONS}

Conducting interdisciplinary northern research to address complex environmental problems such as those in Fort Resolution and the SRD poses a spectrum of challenges. In the following section, we focus on two matters that are particularly relevant to this research, but also have broader implications. The first involves developing and maintaining partnerships and collaboration with community-based organizations. Although many partnership and collaboration issues are associated with non-local partner groups and organizations (e.g., government departments), we focus on the local level because it represents a key point of interaction. The second issue we address centres on documenting change through interdisciplinary analysis and connecting outcomes to the policy process.

\section{Developing Community Partnerships}

Partnerships and collaboration have been identified as increasingly important components of research in northern Canada (Krupnik and Jolly, 2002; Armitage and Clark, 2005). They were prominently featured in the DNR (Graham and Fortier, 2005) and are expected in the programs supported by the tri-council federal funding agencies. The rationale for building such relationships is clear: research will have greater applied and policy relevance where it develops multi-stakeholder partnerships or fosters collaboration among researchers, communities, and other stakeholder interests.

The three components of our research initiative have been developed in close contact with the community of Fort Resolution, and each fosters the involvement of local residents in various aspects of the research process. This is not a claim that all components emerged in the same way or were guided by local priorities to the same extent. For instance, the TK component was a direct response to a suggestion by community leaders following positive interactions with the hydroecological component, and it has been designed in accordance with community expectations. The hydroecological and adaptive capacity components were, and continue to be, more strongly shaped by the research team in response to community concerns. Regardless, in all three components much effort has been directed towards building a strong partnership with key community organizations. In particular, members of the FREWC are regularly informed of research activities and progress. This occurs through the annual and standardized research licence renewal process, which is reviewed by the FREWC, as well as through formal presentations that highlight objectives, preliminary findings, ongoing activities with the local school, and plans for upcoming field studies (with digital copies provided). In our experience, face-to-face oral communication has been the most useful means of keeping members of the community informed about the evolving research program. Furthermore, this 
direct communication allows the research team an opportunity to respond to questions that may have arisen from the research reports and presentations and to obtain feedback from the FREWC regarding research directions. The ongoing information exchange and partnership development with the FREWC is an especially significant element of our research program. Indeed, it was during our first field visit in September 2002 that FREWC members asked us to complement the planned paleolimnological studies with a TK component, providing the impetus for developing the TK and social science thematic components, as previously described.

An especially rewarding partnership has also been formed with the principal, staff, and students of the local Fort Resolution Deninu School. During our numerous field visits, the school has routinely made a classroom available to our research team for processing sediment and water samples, as well as providing access to school computers, telephones, and storage facilities. Use of local infrastructure has clearly enhanced our ability to conduct northern field research, saving us several thousand dollars per year on shipping and storage of field and laboratory equipment and supplies.

These arrangements have also created excellent educational outreach and employment opportunities. During field visits that coincide with the school year, members of the research team routinely give slide shows and laboratory tours and offer local field trips to complement the school curriculum. To provide a more formal training opportunity, the team employed a local high school student to assist in field studies and the laboratory processing of samples collected during an extended field campaign in 2003. High school students were recently approached to take on an active research role and contribute directly to the objectives of the TK study by interviewing elders and land users while fulfilling their community service requirements. Steps have been taken to initiate this process, including an introduction to the concept of environmental change, joint questionnaire development, a mock interview session, and guidance in the operation of video recording equipment. To facilitate transfer of knowledge, a new joint initiative between the Deninu School and the research team aims to develop an educational CD-ROM on the theme of environmental change in the Slave River Delta, incorporating TK and natural science, as well as community impact and adaptation issues.

Positive partnerships have been developed with the school, the FREWC, and the DKFN, but this aspect of interdisciplinary northern research is not without challenges. In particular, and in the context of the emerging northern research paradigm, specific problems may emerge when natural and social science researchers and the funding agencies that promote (and expect) partnerships and collaboration do not reflect on how partnerships and collaboration evolve on the ground in northern research contexts. There are, in fact, many different types of possible partnerships and collaborative processes. In any case, formalized partnerships may not be desired by communities and may also be problematic for researchers, who are obligated to provide documentation of the partnership or of the changing status of partners to funding agencies. This is not necessarily an issue, but it can lead to a further imposition on or a higher level of commitment from the community partner, which may be required to provide written statements of support or other documentation. Thus, the bureaucratization and accounting of partnerships as part of the evolving northern research paradigm reduces flexibility and may create disincentives for productive (but often ad-hoc) partnerships.

Berkes' (1994) typology of forms (or ladder) of comanagement based on experience in northern Canada offers some useful insights. As in co-management, research partnerships and collaborative processes of many types can exist, each with different implications, opportunities, and challenges. The most basic form of interaction simply involves informing the community about research activities, or providing information to the community after research has taken place. More involved partnerships and collaborative processes, however, are increasingly demanded and required for interdisciplinary research, and these include full community control over the research process (defining goals, objectives, approaches, and information dissemination); establishing advisory committees to guide the activities of external researchers; or more generally, engaging researchers and communities in more detailed processes of cooperation and communication. These more demanding forms of researcher-community partnerships envisioned by funding agencies create their own complexities. We therefore try to illustrate some of the opportunities, challenges, and issues inherent in building and maintaining partnerships, and highlight the need for clarity regarding what partnerships and collaboration entail for interdisciplinary research in northern regions.

Partnerships can play a beneficial role in building the knowledge, awareness, and capacity of individuals and communities in northern regions. As highlighted in the outcomes of the DNR, for example, research efforts should "help develop resident capacity and northern involvement in all stages of research in local, national and international issues" (Graham and Fortier, 2005:24). A number of activities within our interdisciplinary research initiative are responding to this challenge, including collaborations with the school and the hiring of community-based researchers to facilitate natural and social science activities. With respect to school-based activities, we have found, for example, that simple demonstrations of various field and laboratory equipment are an effective means of engaging students at all grade levels. However, activities have to be targeted and delivered in a manner suitable to the academic level of the students (something which we have struggled with at times), recognizing that the level and breadth of understanding are quite variable. It is important to note as well that the success of working with the school in Fort Resolution has much to do with its principal, who has been 
very supportive of the research team and views the presence of researchers from outside the community as a positive way to expose students to different career possibilities.

With respect to hiring community researchers, our experiences have been mixed. In one case, efforts to create a unique opportunity for a high school student were problematic-the student simply had difficulty taking on the responsibility of the position. Unfortunately, that student also happened to be the only applicant for the position. In another instance, a senior student proved very helpful to the social science team by making contacts and scheduling interviews with local harvesters and elders, and by working as a videographer at the MAGS/GEWEX-sponsored workshop. Obviously, finding someone with the right "fit" takes time, and one is bound to experience misstarts-and in this sense, the process is not much different from finding the right people for employment in other contexts. However, various circumstances may influence residents' interest in or availability for serving as community researchers and lead to unexpected challenges, and sensitivity to these factors on the part of researchers will help reduce frustration and poor communication. Individuals often have other priorities, including land-use activities, family roles and responsibilities, and the prospect of other seasonal (and more highly paid) employment opportunities and pressures. In Fort Resolution, for example, summer jobs in litter collection will pay students a higher wage than a typical summer research internship (even when wages are adjusted upward to the extent possible). The limited opportunities for students and others in northern communities to develop the interests, skills, and experience that provide the confidence to participate in research activities are a further obstacle. Given the challenging academic environment in many northern communities, the motivation to participate in research activities may be low, resulting in fewer suitable employees. Despite the variability of success and the time requirements involved in creating employment opportunities for students and other community members, continued attempts to do so are warranted.

The DNR highlights a further issue important to building partnerships and collaborative arrangements, specifically calling for agencies that fund research to "emphasize territorial-based research and the importance of reporting back to the community, capturing its interest and exchanging ideas" (Graham and Fortier, 2005:24). The value of this emphasis is straightforward, but it is important for funding agencies and researchers to recognize that engaging the community on the ground is complex and timeintensive if done effectively - and we don't suggest here that our experience represents a best practice, only that there is much effort directed toward this goal. For example, individuals and community groups who may be partners in the research have many different interests and pressures. Contrary to some southerners' notions that life in northern communities is uneventful and community members should be readily available to researchers, the pace and politics in these locations can be intense.
Researchers, especially those from the South, are just one element within a range of interests and activities occurring in northern communities at any given time. Valuing one's research activities over the immediate interests of community members or leaders may undermine trust-building efforts.

Greater clarity is also needed about the nature of the researcher-community relationships that are formed: in many instances, there is an economic subtext to such partnerships. Opportunities to participate in the wage economy (e.g., from renting boats, acting as a guide, sampling, etc.) are important in northern communities where individuals engage in diversified livelihood activities. As well, the expectation of honoraria, particularly in social science research, also influences the way in which relationships are developed. The economic subtext of many research-related partnerships (FREWC members, for instance, are paid an honorarium when meeting), however, should not cause us to infer that the motives behind evolving partnerships are not pure, but rather that there is an economic rationality to many partnerships that is not likely to disappear over a few field seasons. Greater recognition by funding agencies and researchers of this aspect of partnerships in northern regions is likely warranted.

How individuals and community groups are engaged, and who is engaged, are also critical issues that factor into the partnership equation. Northern communities are generally not homogenous either in their composition or with regard to the individual interests of community members. A particular issue in the Fort Resolution situation that has implications for the depth of partnership development centres on the relationships between local organizations representing the DKFN and those representing the Métis. For instance, the FREWC is run out of the DKFN office and largely supports Dené interests, while the local Métis organization engages in its own environmental projects based on the interests of its members, using available funding from external sources. Where environmental issues are concerned, coordination between the two groups may be limited; thus, building partnerships with one may create tensions with the other. As a research team, we have been less successful (and likely less focused) on engaging with the political structures of the Métis in Fort Resolution, mostly because the DKFN is the dominant community organization and represents the largest demographic group. Outside of the formal band and community council structures (e.g., within the school), this distinction is not as important, and the social science components are addressing the broad spectrum of community members. However, in developing the partnerships and collaboration envisioned by funding agencies and in the discourse of northern research agendas, such realities cannot be readily ignored.

Engagement with key community interests to foster partnerships and collaboration presents other challenges as well. For example, even within the DKFN structure and community, information that flows to the FREWC may not necessarily flow out to other stakeholder groups. The reasons for this are not negative; rather, the membership of 
organizations that represent the community is often fluid. The revolving membership and leadership capacity within the FREWC present a considerable, ongoing challenge in ensuring the continuing success of this partnership. In this dynamic context, we have found that repeated interactions are essential to maintain continuity but also to explain the complexity and intricacies of the rather broad spectrum of research being conducted. The latter role has been enhanced by direct voluntary participation of FREWC members in our studies. These volunteers include one member who was trained to operate a meteorological station we established at the local airport from May to September 2005, and others who (as active land users) have participated as steering committee members, as interviewees for the TK research component, and as focus group members for the adaptive capacity component.

The consistency and continuity of research engagement and relationships is further influenced by the fact that individuals in northern communities come and go on a fairly regular basis because of various circumstances. Influencing factors include seasonal employment opportunities, plans to stay with family in other communities or to spend time on the land, and a considerable number of centralized meetings requiring Aboriginal member participation from disparate communities, all of which should be factored into the research planning and implementation process. For university-based researchers, on the other hand, field work most often takes place during the nonteaching part of the year-a time when community members are less likely to be available. When building partnerships and collaboration, therefore, fluid memberships of key organizations should not necessarily be interpreted as a lack of interest or an effort to undermine communication or the sharing of information. Nonetheless, it is a reality of the collaborative process, in which researchers may find themselves revisiting issues they thought had previously been addressed to the satisfaction of community representatives (such as the establishment of a TK data collection protocol). Thus, more time must be factored into the expectations for researchers and those that fund them. Furthermore, for researchers working in the North, political affiliations in northern communities are often very difficult to understand, interpret, and navigate without having a fairly lengthy association with a particular community. Sensitivity to such circumstances on the part of researchers will help mitigate the inevitable miss-steps.

Community-researcher partnerships face many challenges and interesting nuances, with subtexts around power within the community, economic incentives, and many other sociocultural attributes that we have not addressed in detail. There is no substitute for engaging in a long-term process of partnership building and collaboration. This fact has implications for what can be expected in terms of productivity from research that is dependent on these partnerships-an issue for both researchers and the organizations that fund them. In the case of our interdisciplinary work in the SRD, much of the more formalized effort to build partnerships began in 2002, with the start of the hydroecological research component. When the TK component was initiated in 2003 , it was not only the more recent relationships that were important (although these were fundamental), but also community members' positive identification of the new researchers as colleagues of Dr. Mike English, who first started working in the delta during the 1970s. We don't wish to overstate this aspect of the research, but the entrée into the community provided by the long-term and positive association of one individual was an important component of building trust, helpful with respect to the hydroecological research, and quite possibly necessary for the TK component.

\section{Documenting Change through Interdisciplinary Research Approaches}

Spearheading hydroecological research in the SRD is the use of isotope tracers to assess water balance in lakes and detect events such as high-water flooding from distributary channels. Water isotope tracers offer a convenient method of assessing controls on lake water balances because isotopic partitioning in the hydrological cycle is well understood, and a rapid survey of many basins at a single point in time can be acquired without the need for field-intensive, site-specific investigations (see Edwards et al., 2004). This technique has been used extensively in hydrological studies to characterize spatial and temporal variability in the water balance of lakes in other regions of northern Canada (e.g., Gibson, 2001; Gibson and Edwards, 2002), including the Peace-Athabasca Delta (Wolfe et al., 2007). Below we demonstrate the utility of water isotope tracers to map the spatial extent of a moderate flood event in the SRD during the 2003 spring breakup. Implications have particular relevance for interdisciplinary research, as the results provide an effective visual aid to examining the effects of flooding on the socioeconomic activities of community members in Fort Resolution.

When plotted on a standard $\delta^{2} \mathrm{H}-\delta^{18} \mathrm{O}$ diagram (Fig. 3a), results from oxygen and hydrogen isotope analyses on lake water samples obtained from the SRD on 23 May 2003 show two distinct populations of lakes. Clustering of lake water isotopic compositions near the value obtained for the Slave River suggest that these basins have recently received input of river flood water, whereas the larger spread of data points farther to the right of the Global Meteoric Water Line are from basins that have undergone more substantial evaporation in the absence of river flood inputs. Comparison of $\delta^{18} \mathrm{O}$ values to total suspended sediment (TSS) concentrations sampled from the same basins reveals that many basins with low $\delta^{18} \mathrm{O}$ values display higher TSS values, consistent with field observations at these sites of turbid water, evidently derived from high loads of suspended material carried by floodwaters of the Slave River (Fig. 3b). These data provide the basis for mapping the spatial extent of flooding in spring 2003, 
a)

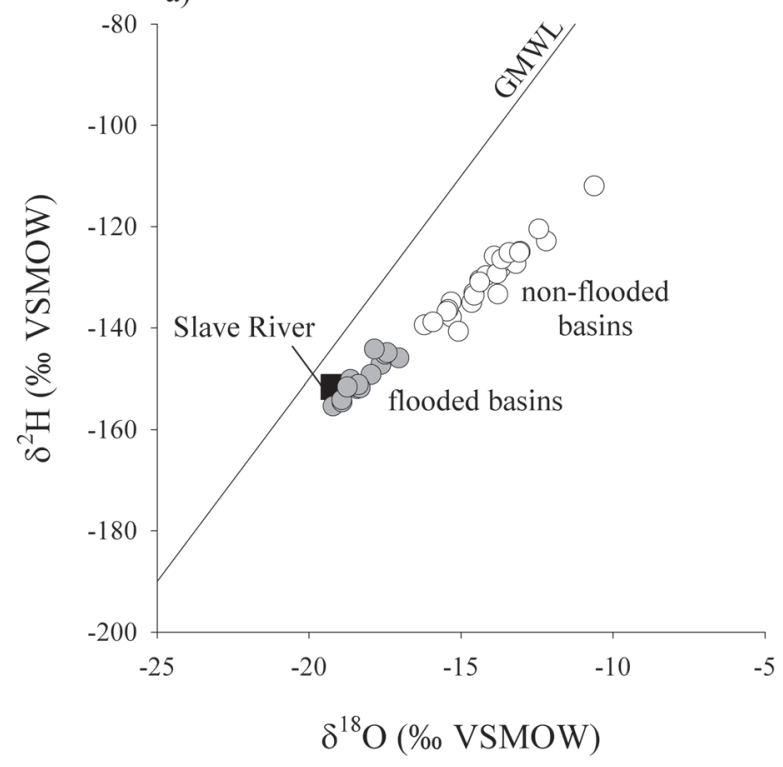

b)

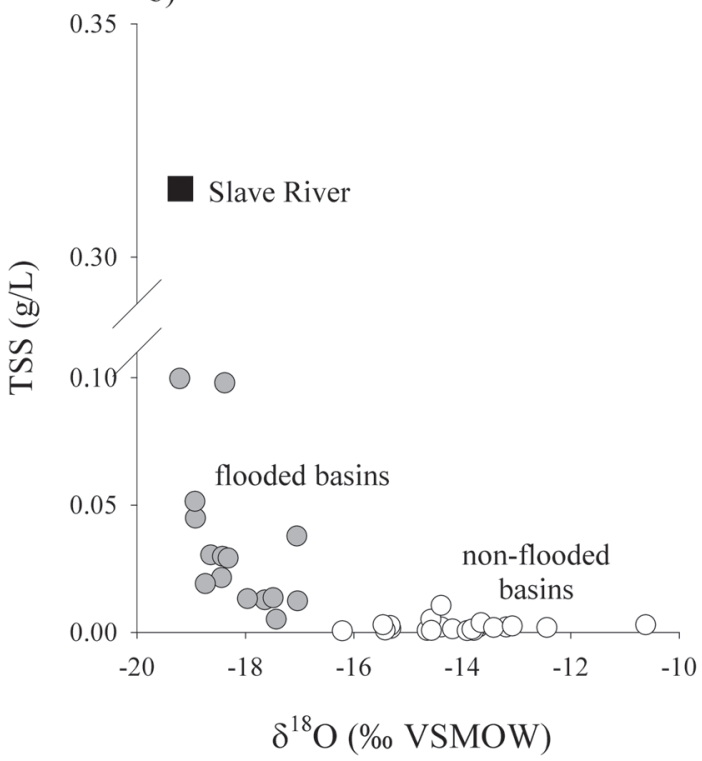

percent dilution

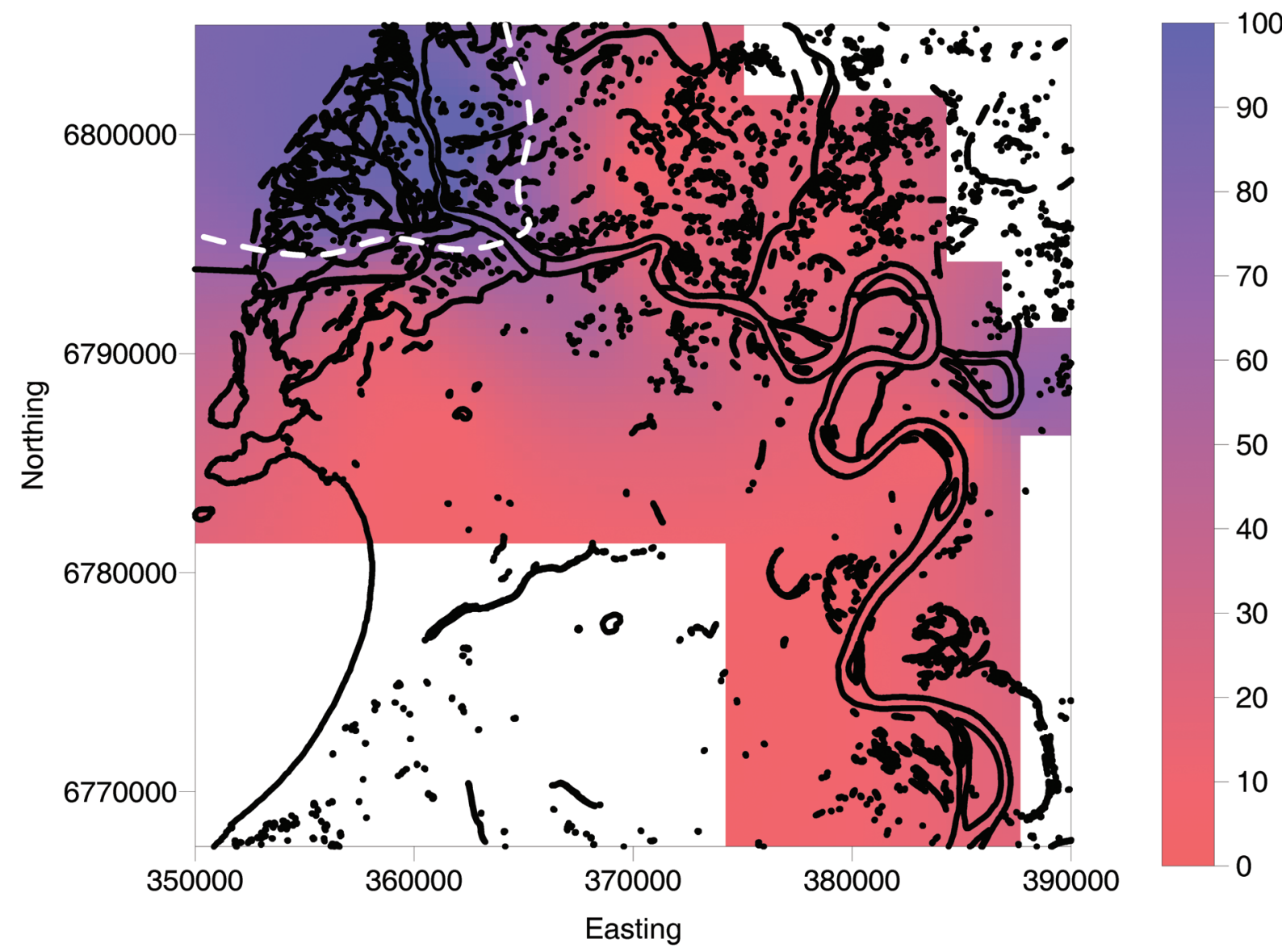

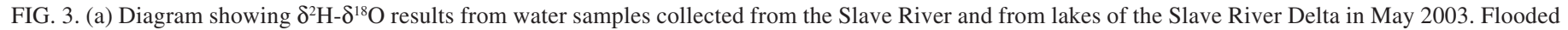

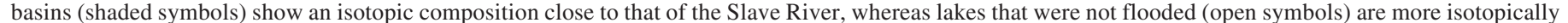

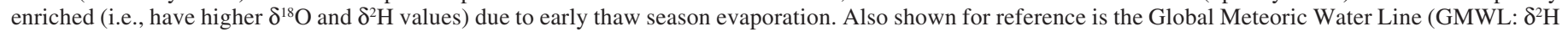

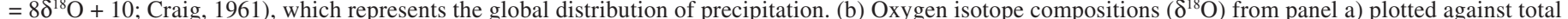

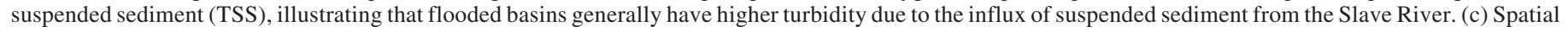

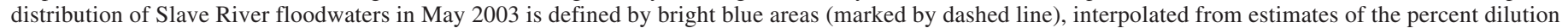
of lake water volume (Brock et al., in press). 
which was restricted to areas adjacent to the main distributary channels of the Slave River in the mid and outer portions of the active delta (Fig. 3c). As further discussed in Brock et al. (in press), documentation of flooded versus non-flooded basins sets the stage for identifying the effect of this hydrological process on lake water balances in the SRD as they evolved over the course of the 2003 open-water season, and for distinguishing subregions of the delta that are sensitive to the effects of hydrologic versus climatic change.

Mapping the distribution of floodwaters provides a useful illustrative tool for examining connections between this important hydrological process and wildlife, trapping, and hunting patterns during specific years, as will be determined from discussions that are currently being held with local residents. While the final outcomes of this research remain to be seen, it is interesting to point out that during a presentation to the FREWC in May 2005, which included a broad assemblage of preliminary hydrological, limnological, and TK results, the "flood map of 2003" easily garnered the most attention from committee members, and considerable subsequent discussion focused on precisely what the map meant and how it could be further used. Indeed, the "flood-mapping" exercise has led to new questions that directly link with the objectives of the TK study: 1) how often does a flood of the 2003 magnitude occur? 2) When did a flood of greater magnitude than the 2003 flood last occur? and 3) Were there any distinctive patterns in wildlife distribution following the flood event of 2003?

Subsequent hydroecological monitoring has revealed that in 2004 there was limited spring flooding, whereas in spring 2005 a major flood event took place, extending well upstream along the floodplain of the Slave River. This broad range in hydrological variability observed since the initiation of our research program provides an excellent template and opportunity to elucidate linkages between hydroclimatic drivers and hydroecological responses in the delta, relationships with interannual variability in wildlife patterns and local harvesting, and recent observations of major flood events. Furthermore, the combined efforts of paleolimnological and TK approaches to reconstructing a longer-term record of Slave River flood frequency will provide an important temporal context for hydrological observations and data collected over the past few years.

We anticipate, however, that practical integration of results using natural science approaches and TK to address multi-dimensional environmental issues of the SRD and community of Fort Resolution will be associated with its own set of challenges. These may include the comparative analysis of quantitative measurements versus qualitative observations with varying time and space relevancy, difficulties in assessing observational uncertainties, and effective transfer of knowledge to community members and decision makers. An outcome of the DNR is the suggestion that the research community should "recognize the needs and values of Aboriginal cultures and traditional knowledge" (Graham and Fortier, 2005:26). Although there is much progress in this regard, barriers remain-not least of which is the difficulty in linking natural science and TK observations and the time commitment required to conduct interdisciplinary research. Other barriers are more structural: the academic reward system and the funding tied to that system are not always conducive to interdisciplinary research or a policy focus. This may be changing, albeit slowly, and there are good examples of why change towards integration is likely to continue (see Berkes et al., 2005). As illustrated by studies in the PAD, comparison of paleolimnological data with TK and other historical sources to identify changes in flood frequency over the past $~ 300$ years has proven successful, with significant implications for ecosystem management (Wolfe et al., 2006b).

Discussions at the FREWC meeting noted above indicated the potential for combining flood mapping and TK observations to inform the community about changes relevant to lands, resources, and local livelihoods. This example of engaging FREWC members in discussion of preliminary results has had an important, positive ancillary effect on the overall and ongoing FREWC support of our interdisciplinary research initiatives. A more widespread buy-in to such opportunities by a broader crosssection of the community, however, depends on resolving a number of intransigent issues. The DNR highlights the need to "access and record traditional knowledge with due urgency" (Graham and Fortier, 2005:26), although in many research contexts there is a real danger that TK may simply be "mined" for empirical insights that are compatible with a Western-science process, neglecting the sociocultural, philosophical, and even spiritual foundations of that knowledge. Efforts to avoid the misappropriation of TK must therefore be central to the research, although there is limited agreement on how to approach this challenge. Specific protocols to guide TK studies, developed jointly by researchers and community partners, can help in this regard. However, there are no standardized tools or methods designed to foster integration. Knowledge integration will be most successful in contexts where trust-building has been a precondition of project implementation, and where the different groups engaged in interdisciplinary research share a mutual respect for diverse perspectives. Thus, the focus on integration is perhaps less critical than a commitment to give equal value to the insights of elders and harvesters explored through TK research. Analytical processes and recommendations that emerge from Western science and TK research may therefore follow parallel tracks, with a shared orientation towards the resolution of a commonly defined problem.

\section{CONCLUDING COMMENTS}

Although there are no blueprints to guide the development of research that is collaborative, interdisciplinary, policy-oriented, and reflective of northern priorities, lessons learned from our experiences offer some useful 
insights. For instance and perhaps most importantly, efforts from the outset of our research initiative have consistently been directed towards building strong relationships with community organizations. Numerous interactions of the researchers with the local school, key local organizations like the environmental committee, and community leaders (formal and informal) have led to positive outcomes, despite the challenges associated with that process. While it is more widely recognized that researchers engaged in social science research will benefit from repeated interactions with the community, our experience, like that of others (e.g., NRBS; Gummer et al., 2000), indicates there is a good argument for natural scientists to incorporate repeated interactions into their work as well. For residents, community leaders, and researchers confronting the complexities and uncertainties of climate change and its impacts in the North, repeated and collaborative interactions are likely to foster more informed analysis, decision making on resource management, and environmental stewardship.

\section{ACKNOWLEDGEMENTS}

Our research has been significantly enhanced by the assistance and support of the residents of Fort Resolution, and especially the principal and staff of the Deninu School, as well as members of the Fort Resolution Environmental Working Committee. We are grateful to the many agencies that support our interdisciplinary research in Fort Resolution and the Slave River Delta, including NSERC's Northern Research Chair Program, SSHRC's Northern Research Development Program, the Canada Foundation for Innovation and the Ontario Innovation Trust, the Government of Ontario Premier's Research Excellence Award, the Polar Continental Shelf Project, the Climate Change Impacts and Adaptations Program of Natural Resources Canada, the Northern Scientific Training Program of Indian and Northern Affairs Canada, the Oceans Management Research Network, the Human Resources Development Canada Summer Career Placements Program, and BC Hydro. Special thanks to Dr. Mike English, whose long-established research connections with the people of Fort Resolution through his work on the Slave River Delta opened the door to the successful launching of our interdisciplinary research program. Finally, we acknowledge the insightful and constructive comments of two manuscript reviewers and the editor, as well as the input provided by Doug Clark on an earlier draft.

\section{REFERENCES}

ACIA (ARCTIC CLIMATE IMPACT ASSESSMENT). 2004. Impacts of a warming climate. Cambridge: Cambridge University Press. 140 p.

AGRAWAL, A. 1995. Dismantling the divide between indigenous and scientific knowledge. Development and Change 26: $413-439$.
ARMITAGE, D., and CLARK, D. 2005. Issues, priorities and research directions for oceans management in Canada's North. In: Berkes, F., Huebert, R., Fast, H., Manseau, M., and Diduck, A., eds. Breaking ice: Renewable resource and ocean management in the Canadian North. Calgary: Arctic Institute of North America and University of Calgary Press. 337-362.

BERKES, F. 1994. Co-Management: Bridging the two solitudes. Northern Perspectives 22:18-20.

1999. Sacred ecology: Traditional ecological knowledge and resource management. Philadelphia: Taylor and Francis.

BERKES, F., HUEBERT, R., FAST, H., MANSEAU, M., and DIDUCK, A. 2005. Breaking ice: Renewable resource and ocean management in the Canadian North. Calgary: Arctic Institute of North America and University of Calgary Press.

BILL, L., CROZIER, J., and SURRENDI, D. 1996. A report of wisdom synthesized from the traditional knowledge component studies. Northern River Basins Study Synthesis Report No. 12. Edmonton: Northern River Basins Study.

BROCK, B.E., WOLFE, B.B., and EDWARDS, T.W.D. In press. Characterizing the hydrology of shallow floodplain lakes in the Slave River Delta, NWT, using water isotope tracers. Arctic, Antarctic and Alpine Research.

CRAIG, H. 1961. Isotopic variations in meteoric waters. Science 133:1702-1703

EDWARDS, T.W.D., WOLFE, B.B., GIBSON, J.J., and HAMMARLUND, D. 2004. Use of water isotope tracers in high-latitude hydrology and paleohydrology. In: Pienitz, R., Douglas, M., and Smol, J.P., eds. Long-term environmental change in Arctic and Antarctic lakes, Developments in Paleoenvironmental Research 7. Dordrecht: Springer. 187-207.

ENGLISH, M.C., HILL, R.B., STONE, M.A., and ORMSON, R. 1997. Geomorphological and botanical change on the outer Slave River Delta, NWT, before and after impoundment of the Peace River. Hydrological Processes 11:1707-1724.

GIBSON, J.J. 2001. Forest-tundra water balance signals traced by isotopic enrichment in lakes. Journal of Hydrology 251:1-13.

GIBSON, J.J., and EDWARDS, T.W.D. 2002. Regional surface water balance and evaporation-transpiration partitioning from a stable isotope survey of lakes in northern Canada. Global Biogeochemical Cycles 16(2). DOI: 10.1029/2001GB001839.

GNWT (GOVERNMENT OF THE NORTHWEST TERRITORIES). 1993. Traditional knowledge policy. Yellowknife: Government of Northwest Territories.

GRAHAM, J., and FORTIER, E. 2005. From opportunity to action: A progress report on Canada's renewal of northern research. Report submitted by the Institute On Governance to the Planning Committee for the Dialogue on Northern Research. Ottawa: Natural Sciences and Engineering Research Council of Canada. 78 p. http://www.nserc.gc.ca/about/NorthRes_06-05_e.pdf.

GUMMER, W.D., CASH, K.J., WRONA, F.J., and PROWSE, T.D. 2000. The Northern River Basins Study: Context and design. Journal of Aquatic Ecosystem Stress and Recovery 8:7-16.

HALL, R.I., WOLFE, B.B., and EDWARDS, T.W.D. 2004. A multi-century flood, climatic, and ecological history of the Peace-Athabasca Delta, northern Alberta, Canada. Final Report. Vancouver: BC Hydro. 163 p + Appendices. Available from the lead author. 
HANSON, S., and VANFLEET, J. 2003. Traditional knowledge and intellectual property: A handbook on issues and options for traditional knowledge holders in protecting their intellectual property and maintaining biodiversity. Washington, D.C.: American Association for the Advancement of Science.

KORSMO, F.L., and GRAHAM, A. 2002. Research in the North American North: Action and reaction. Arctic 55(4):319-328.

KRUPNIK, I., and JOLLY, D. 2002. The earth is faster now: Indigenous observations of Arctic environmental change. Fairbanks: Arctic Research Consortium of the United States. $356 \mathrm{p}$.

McDONALD, M., ARRAGUTAINAQ, L., and NOVALINGA, Z. 1997. Voices from the Bay: Traditional ecological knowledge of Inuit and Cree in the Hudson Bay bioregion. Ottawa: Canadian Arctic Resources Committee and Sanikiluaq: Environmental Committee of Municipality of Sanikiluaq.

MILBURN, D., MACDONALD, D.D., PROWSE, T.D., and CULP, J.M. 1999. Ecosystem maintenance indicators for the Slave River Delta, Northwest Territories, Canada. In: Pykh, Y.A., Hyatt, D.E., and Lenz, R.J.M., eds. Environmental indices: Systems analysis approach. Oxford: EOLSS Publishers Co. Ltd. 329-348.

MONGEON, C.L., WOLFE, B.B., EDWARDS, T.W.D., and HALL, R.I. 2006. Climate-driven co-variance in isotope paleohydrology: Slave River and Peace-Athabasca deltas. Duluth: International Paleolimnology Symposium.

PADIC (PEACE-ATHABASCA DELTA IMPLEMENTATION COMMITTEE). 1987. Peace-Athabasca Delta Water Management Works Evaluation: Final Report, with appendices. Governments of Canada, Alberta, and Saskatchewan.

PADPG (PEACE-ATHABASCA DELTA PROJECT GROUP). 1973. Peace-Athabasca Delta Project, Technical Report and Appendices. 2 vols. Governments of Canada, Alberta, and Saskatchewan.

PADTS (PEACE-ATHABASCA DELTA TECHNICAL STUDIES). 1996. Final Report. Fort Chipewyan, Alberta: PADTS Steering Committee.

PROWSE, T.D., CONLY, F.M., CHURCH, M., and ENGLISH, M.C. 2002. A review of hydroecological results of the Northern River Basins Study, Canada, Part 1: Peace and Slave Rivers. River Research and Applications 18:429-446.
SHERRY, E., and MYERS, H. 2002. Traditional environmental knowledge in practice. Society and Natural Resources 15: $345-358$.

SILLITOE, P. 2002. Indigenous knowledge development in Bangladesh: Present and future. Dhaka, Bangladesh: Intermediate Technology Publications/The University Press.

STEVENSON, M. 1996. Indigenous knowledge in environmental assessment. Arctic 49(3):278-291.

TIMONEY, K. 2002. A dying delta? A case study of a wetland paradigm. Wetlands 22:282-300.

USHER, P. 2000. Traditional ecological knowledge in environmental assessment and management. Arctic 53(2):183-193.

WEIN, R.W. 2002. Northern research legacies and the future: A university perspective. Arctic 55(4):iii-iv.

WOLFE, B.B., EDWARDS, T.W.D., and HALL, R.I. 2002. Past and present ecohydrology of the Peace-Athabasca Delta, northern Alberta, Canada: Water isotopes lead the way. PAGES News 10:16-17.

WOLFE, B.B., KARST-RIDDOCH, T.L., VARDY, S.R., FALCONE, M.D., HALL, R.I., and EDWARDS, T.W.D. 2005. Impacts of climate and river flooding on the hydro-ecology of a floodplain basin, Peace-Athabasca Delta, Canada since A.D. 1700. Quaternary Research 64:147-162.

WOLFE, B.B., HALL, R.I., and EDWARDS, T.W.D. $2006 a$. Assessing the status of the Peace-Athabasca Delta ecosystem: Challenging the paradigm from a paleoenvironmental perspective. Meridian Fall/Winter:7-12.

WOLFE, B.B., HALL, R.I., LAST, W.M., EDWARDS, T.W.D., ENGLISH, M.C., KARST-RIDDOCH, T.L., PATERSON, A., and PALMINI, R. 2006b. Reconstruction of multi-century flood histories from oxbow lake sediments, Peace-Athabasca Delta, Canada. Hydrological Processes 20:4131-4153.

WOLFE, B.B., KARST-RIDDOCH, T.L., HALL, R.I., EDWARDS, T.W.D., ENGLISH, M.C., PALMINI, R., McGOWAN, S., LEAVITT, P.R., and VARDY, S.R. 2007. Classification of hydrologic regimes of northern floodplain basins (PeaceAthabasca Delta, Canada) from analysis of stable isotopes $\left(\delta^{18} \mathrm{O}, \delta^{2} \mathrm{H}\right)$ and water chemistry. Hydrological Processes 21 : $151-168$. 